\title{
Konformitas Internalisasi Siswa Terhadap Peraturan Sekolah dan Implikasinya dalam Layanan Bimbingan dan Konseling
}

Fatmi Yulfitri, Marjohan, \& Afrizal Sano

Universitas Negeri Padang

\begin{abstract}
Internalization of conformity need to be developed in education. Development of internalization of conformity in school environment make students can optimize their internal ability to think, feel, consider everything in behaving to obey school rules. In fact the social causes make students adhere to school rules such as fear sanctioned, want to be praised. Shame ridiculed friends and others. This research aims to describe student's internalization of conformity with the regulations of arrival and presence, rules in learning and common rules in school and their implications in guidance and counseling services. The method used is descriptive research. The instrument research is quistionnaire. The population in this research was all students MAN 1 Model Bukittinggi and samples are 90 people. The finding of the research revealed that most of internalization of conformity student for rules relatively middle in schools relating to the regulation of arrival and presence, rules in learning and common rules in school.
\end{abstract}

Keyword: Internalization of conformity, School rules

Copyright (C 2014 IICE - Multikarya Kons (Padang - Indonesia) dan IKI - Ikatan Konselor Indonesia - All Rights Reserved

Indonesian Institute for Counseling and Education (IICE) Multikarya Kons

\section{PENDAHULUAN}

Peraturan sekolah merupakan unsur yang penting dalam dunia pendidikan. Peraturan ditegakkan untuk meningkatkan disiplin pada diri siswa dan menjadikan siswa yang memiliki kepribadian yang baik. Sutjipto dan Basori (1989: 52) menjelaskan bahwa disiplin merupakan aspek penting di dalam pembinaan siswa, karena siswa harus menyadari bahwa di dalam kehidupan bermasyarakat diperlukan kedisiplinan. Dengan adanya kedisiplinan pada diri siswa maka tujuan pendidikan akan tercapai.

Dalam mentaati peraturan sekolah, siswa patuh terhadap peraturan karena adanya pengaruh sosial. Pengaruh sosial yang terjadi dalam hubungan pendidikan disebut konformitas. Menurut Robert A.Baron dan Donn Byrne (2003: 53) "konformitas merupakan suatu jenis pengaruh sosial dimana individu mengubah sikap dan tingkahlaku mereka agar sesuai dengan norma sosial yang ada".

Konformitas dapat berbentuk konformitas membabi buta, konformitas identifikasi dan konformitas internalisasi. Konformitas internalisasi perlu dikembangkan dalam pendidikan. Konformitas internalisasi pada diri siswa terjadi dengan adanya kekuatan pikiran, perasaan, pengalaman, hati nurani dan semangat untuk menentukan pilihan dalam berfikir dan berpendapat. (Prayitno, 2009: 72-74).

Berdasarkan wawancara yang peneliti lakukan tanggal 18 Februari 2013 kepada 5 orang siswa MAN 1 Model Bukittinggi terungkap bahwa mereka pada umumnya pernah terlambat dan ada yang beberapa kali. Mereka merasa jadwal masuk sekolah terlalu cepat dan membuat mereka keberatan dengan peraturan kedatangan yang diterapkan di sekolah mereka. Siswa tersbut juga mengatakan bahwa takut diberi sanksi dan dipanggil guru BK jika melanggar peraturan sekolah.

Berdasarkan wawancara yang peneliti lakukan kepada guru BK MAN 1 Model Bukittinggi dan rekap data absen dari kelas X, XI, XII bahwa tiap hari siswa banyak yang terlambat dan tidak hadir atau alfa. Pada bulan September 2013 siswa yang terlambat sebanyak 14 orang kelas X, 29 orang kelas XII dan 39 orang kelas XII. 
Siswa yang absen sebanyak 5 orang kelas X, 15 orang kelas XI dan 22 orang kelas XII. Siswa tersebut diproses di ruang BK kemudian diberi sanksi sesuai dengan skor pelanggaran. Kemudian saat upacara bendera banyak siswa yang kedapatan memakai aksesories berlebihan seperti gelang. Lalu guru BK mengambil aksesories tersebut dan tidak mengembalikannya.

Dari fenomena tersebut terlihat bahwa kekuatan- kekuatan manuasiawi siswa seperti pikiran, perasaan, pengalaman, hati nurani semangat dan bertingkah laku (konformitas internalisasi) siswa untuk mematuhi peraturan sekolah belum terlihat. Untuk itu diperlukan upaya guru BK dalam mengembangkan kekuatan-kekuatan internalisasi siswa dalam mematuhi peraturan sekolah sehingga dengan sendirinya siswa menyadari pentingnya peraturan sekolah tersebut. Oleh sebab itu, penulis ingin meneliti mengenai Konformitas Internalisasi Siswa terhadap terhadap Peraturan Sekolah di MAN 1 Model Bukittinggi dan Implikasinya dalam layanan Bimbingan dan Konseling

\section{METODOLOGI PENELITIAN}

Penelitian ini menggunakan metode kuantitatif dengan pendekatan analisis deskriptif. Populasi penelitian ini adalah semua siswa MAN 1 Model Bukittinggi, sedangkan sampel dalam penelitian ini berjumlah 90 orang. Instrumen yang digunakan untuk mengumpulkan data dalam penelitian ini adalah angket. Jenis angket yang digunakan dalam penelitian ini adalah angket tertutup dengan menggunakan skala model likert dengan lima alternatif pilihan jawaban SangatSesuai (SS) jika tingkat kesesuaiannya 81\%-100\%, Sesuai (S) jika tingkat kesesuaiannya 61-80\%, KurangSesuai (KS) jika tingkat kesesuaiannya 41-60\%\%, Tidak Sesuai (TS) jika tingkat kesesuaiannya 21-40\%, Sangat Tidak Sesuai (STS) jika tingkat kesesuainnya 0\%-20\%, sedangkan untuk data yang diperoleh dianalisis dengan menggunakan teknik persentase yang dikemukakan oleh Nana Sudjana (2001: 129)

Keterangan :

$$
\mathrm{P}=\frac{f}{n} \times 100
$$

$\mathrm{P}=$ Persentase jawaban

$\mathrm{f}=$ Frekuensijawaban

$\mathrm{n}=$ Jumlah keseluruhan responden

Klasifikasi kategori tingkat konformitas internalisasi siswa terhadap peraturan sekolah yaitu:

$$
\begin{aligned}
& 81 \%-100 \%=\text { sangat tinggi } \\
& 61 \%-80 \%=\text { tinggi } \\
& 41 \%-60 \%=\text { sedang } \\
& 21 \%-40 \%=\text { rendah } \\
& 0-20 \%=\text { sangat rendah }
\end{aligned}
$$

HASIL

Berdasarkan hasil pengolahan data, maka hasil penelitian ini dapat digambarkan sebagai berikut :

Tabel 1.

Rekapitulasi konformitas internalisasi siswa terhadap peraturan sekolah

\begin{tabular}{|c|l|c|c|}
\hline No. & \multicolumn{1}{|c|}{ Sub Variabel } & $\begin{array}{c}\text { Persentase } \\
\%\end{array}$ & Kategori \\
\hline 1 & $\begin{array}{l}\text { Konformitas internalisasi siswa terhadap } \\
\text { peraturan kedatangan dan kehadiran }\end{array}$ & 56 & Sedang \\
\hline 2 & $\begin{array}{l}\text { Konformitas internalisasi siswa terhadap } \\
\text { peraturan dalam belajar }\end{array}$ & 54,4 & Sedang \\
\hline 3 & $\begin{array}{l}\text { Konformitas internalisasi siswa terhadap } \\
\text { peraturan umum sekolah }\end{array}$ & 62,1 & Tinggi \\
\hline
\end{tabular}


Dari tabel diatas dapat disimpulkan bahwa: (1) konformitas internalisasi siswa terhadap perturan kedatangan dan kehadiran tergolong sedang dengan persentase $56 \%$ (2) konformitas internalisasi siswa terhadap peraturan dalam belajar tergolong sedang dengan persentase $54,4 \%$ (3) konformitas internalisasi siswa terhadap peraturan umum sekolah tergolong tinggi dengan persentase $62,1 \%$

\section{PEMBAHASAN}

Berdasarkan hasil pengolahan data yang telah dilakukan sebelumnya, berikut ini dikemukakan pembahasan sesuai dengan pertanyaan penelitian yang diajukan:

1. Konformitas internalisasi siswa terhadap peraturan kedatangan dan kehadiran.

Faktor yang menyebabkan siswa mematuhi aturan sekolah yang berkaitan dengan kehadirannya di sekolah bisa disebabkan adanya suatu sanksi. Artinya jika siswa datang kesekolah karena takut diberi sanksi maka dalam diri siswa tersebut terjadi konformitas membabi buta. Seperti yang dijelaskan Prayitno (2009: 72) bahwa konformitas membabi buta diwarnai dengan adanya rasa takut akan sanksi yang membahayakan bagi diri individu. Dalam kaitan ini siswa belum menyadari, menghayati, memikirkan, mempertimbangkan jika ia tidak hadir ke sekolah akan merugikan dirinya seperti ketinggalan pelajaran dan tidak mengerti akan materi pelajaran yang tidak di ikutinya.

Tindakan tegas yang mendidik yang diberikan kepada siswa yang melanggar peraturan sekolah berguna sebagai perbaikan. Menurut Habulllah (2011: 32) bahwa ada beberapa alasan yang mendasari adanya tindakan tegas yang mendidik yaitu alasan memperbaiki; anak memperbaiki perbuatannya, alasan ganti rugi; anak mengganti kerugian akibat perbuatanya, alasan melindungi; orang lain dilindungi sehingga tidak meniru perbuatan yang salah, dan alasan menakutkan; anak takut mengulanginya serta alasan hukuman alam; belajar dari pengalaman.

Perilaku siswa yang tidak melanggar peraturan sekolah seperti absen, cabut dan terlambat juga bisa disebabkan adanya pengaruh orang lain seperti malu ditertawakan teman, takut dipanggil keruang BK serta tidak mendapatkan pujian dari guru. Semua itu mencerminkan bahwa siswa datang dan hadir kesekolah bukan karena dirinya melainkan adanya pengaruh orang lain. Hal ini bukan hal yang baik bagi siswa dalam proses pendidikan.

Pendidikan harus mampu mengembangkan kemampuan internal siswa agar tercipta perilaku yang sesuai dengan norma atau aturan yang berlaku. Seperti yang dikemukakan Prayitno (2009: 81) bahwa proses internalisasi akan menjadikan siswa menjadi diri pribadi yang berkembang melalui suasana bebas yang menjunjung tinggi HMM siswa. Jadi dapat disimpulkan jika proses internalisasi diupayakan oleh guru di sekolah khususnya guru bimbingan dan konseling maka akan menjadikan siswa yang berkembang ke arah yang positif.

\section{Konformitas internalisasi siswa terhadap perturan dalam belajar.}

Temuan penelitian mengungkapkan bahwa konformitas internalisasi siswa berkaitan dengan peraturan dalam belajar tergolong sedang. Namun sebagian lagi siswa yang memiliki konformitas internalisasi negatif dalam memenuhi tuntutan dalam belajar. Di lihat dari fenomena di sekolah yaitu masih ada siswa yang sering keluar masuk kelas ketika guru menerangkan pelajaran, siswa yang tidak membuat PR di rumah, terlambat, absen, mengobrol, memainkan HP, memakan makanan saat belajar, ribut, menyontek serta tindakan lainnya.

Siswa memiliki hak dan kewajiban dalam belajar. Siswa memiliki hak untuk mendapatkan ilmu yang banyak dan memiliki kewajiban mematuhi aturan yang berkaitan dengan belajar. seperti bersikap tenang, penuh konsentrasi, tidak keluar keluar selama proses pembelajaran berlangsung, membuat PR dan lain-lain. Dalam hal ini ada sebagian siswa yang tidak memenuhi tuntutan tersebut dan adanya yang memenuhi tetapi bukan karena dirinya melainkan karena menarik simpati dari orang lain contohnya guru, orang tua dan temantemannya.

Hal ini sesuai dengan yang dikemukakan N.Frandsen (dalam Sumadi Suryabrata, 2012: 236) bahwa ada beberapa hal yang mendorong seseorang untuk belajar yaitu adanya sifat ingin tahu, adanya sifat krestif, adanya keinginan untuk mendapatkan simpati dari orangtua, guru, dan teman-teman, dan adanya keinginan 
memperbaiki kegagalan, serta adanya hukuman atau ganjaran. Jadi guru, orangtua dan teman sebaya juga dapat mendorong seseorang untuk memenuhi tuntutan dalam belajar.

Jika alasan memenuhi tuntutan belajar karena pengaruh orang lain yang disenangi dan disegani maka itu merupakan konformitas identifikasi. Seperti yang dikemukakan Prayitno (2009: 73) bahwa konformitas identifikasi terjadi karena adanya kesukarelaan, kepercayaan, pengakuan, kesenangan dan kepuasaan yang berasal dari seseorang. Namun alangkah lebih baik jika siswa di sekolah mampu memenuhi tuntutan dalam belajar karena ia meyakini belajar untuk kebaikan dirinya sendiri dan demi masa depan siswa.

Bermula dengan adanya pengakuan dan penerimaan siswa terhadap gurunya menjadikan siswa menpercayai, meniru bahkan mengidolakan guru di sekolah. Hal itu senada dengan yang dikemukakan Prayitno (2009: 73) bahwa konformitas identifikasi tergolong lebih manusiawi karena menyentuh anah afektif siswa seperti kesukarelan, kepercayaan, pengakuan, kesenangan dan kepuasaan. Namun internalisasi siswa dapat tumbuh secara berangsur-angsur jika guru menganggap siswa memiliki potensi yang luar biasa, bersemangat dan meiliki kemampuan yang amat besar dalam meraih sesuatu dari guru.

\section{Konformitas internalisasi siswa terhadap peraturan umum sekolah.}

Dalam memenuhi peraturan sekolah ada siswa yang melanggar dan ada siswa yang patuh. Seperti kewajiban siswa menjaga kebersihan lingkungan sekolah. Masih ada siswa yang belum menyadari pentingnya menjaga kebersihan sekolah dan kelas. Padahal dengan menjaga kebersihan kelas dan lingkungan sekolah akan menciptakan suasana belajar yang nyaman, bersih sehingga siswa bisa fokus dan giat karena perhatiannya tidak terpecah oleh buruknya kondisi lingkungan sekolah.

Hal ini sesuai dengan pendapat Tulus (2004: 36) yang menyatakan bahwa lingkungan sekolah yang terartur, tertib, tenang tersebut memberikan gambaran lingkunagn siswa yang giat, gigih, serius, penuh perhatian, sungguh-sungguh dan kompetitif dalam kegiatan pembelajarannya. Jadi menjaga lingkungan sekolah itu penting untuk menciptakan suasana belajar yang nyaman penuh perhatian.

Selanjutnya siswa yang mematuhi peraturan sekolah seperti dilarang untuk tidak melakukan aksi tawuran antar pelajar, umumnya siswa tidak melakukan karena takut diskors. Melakukan aksi tawuran antar pelajar merupakan pelanggaran berat. Siswa yang melakukan akan di skorsing dan bisa dipulangkan ke orangtuanya. Skorsing bisa membuat siswa takut dan jera apalagi hukuman skorsing memang benar-benar diterapkan di sekolah tersebut. Namun alangkah lebih baik jika guru di sekolah mengembangkan kesadaran dan keyakinan siswa bahwa tawuran dan pelanggaran berat lainnya benar-benar sangat merugikan siswa baik itu dari segi belajar, fisik maupun psikologis siswa bukan hanya sekedar ancaman hukuman jika siswa melanggar.

Untuk itu guru berpengaruh dalam rangka mengembangkan internalisasi siswa. Hal ini sesuai dengan pendapat Prayitno (2009: 81) bahwa konformitas internalisasi siswa berlangsung ketika diaktifkannya kekuatan pada diri siswa yaitu kekuatan berfikir, merasakan, berpengalaman yang dipadukan melalui pertimbangan-pertimbangan yang matang terhadap apa yang dilakukan siswa.

Mengembangkan kekuatan internalisasi siswa menjadikan siswa mandiri dan suasana bebas dari lingkungan yang penuh kekuasaan dan karismanya seorang guru. Pengembangan kemampuan internalisasi terjadi secara berangsur-angsur. Sebagaimana yang dikemukakan Prayitno (2009: 79) bahwa dimensi kekuasaan dan karisma dalam pendidikan berpusat pada guru maka dimensi internalisasi berpusat pada siswa.

Dimensi karisma dan kekuasaan mengakibatkan penyerahan diri siswa ke guru maka internalisasi mendorong dan memberikan kesempatan pengembangan kedirian siswa secara berangsur-angsur kepada guru atau pendidik itu sendiri. Jadi kemampuan internalisasi terjadi jika kekuatan-kekutan dalam dirinya berupa pertimbangan rasional, perasaan, nilai dan sikap, pengalamanya digunkan siswa untuk mematuhi peraturan sekolah.

\section{Implikasi dalam layanan bimbingan dan konseling}

Guru bimbingan dan konseling memiliki peranan penting dalam mengembangan kepribadian siswa. Sesuai dengan hasil penelitian mengenai konformitas internalisasi siswa, masih banyak siswa yang harus dikembangkan kekuatan internalisasinya terhadap peraturan sekolah. Maka implikasi layanan bimbingan dan konseling mengenai konformitas internalisasi siswa terhadap peraturan sekolah adalah melalui pemberian 
layanan-layanan BK oleh guru bimbingan dan konseling. Layanan bimbingan dan konseling yang dapat diberikan oleh guru bimbingan dan konseling adalah:

a. Layanan Orientasi

Layanan orientasi dapat diberikan kepada siswa dalam rangka memasuki lingkungan baru (sekolah) saat dalam masa orientasi siswa (MOS). Materi layanan orientasi yang diberikan guru pembimbing dapat berupa pengenalan peraturan sekolah, jenis-jenis pelanggaran dan sanksi. Dengan adanya pengenalan berupa peraturan sekolah, pelanggaran dan sanksi siswa dapat menyesuaikan diri mereka dengan peraturan sekolah tersebut, Siswa paham mengenai peraturan sekolah dan dapat mencegah terjadi pelanggaran terhadap peraturan sekolah.

b. Layanan Informasi

Layanan Informasi diberikan kepada siswa dengan tujuan agar siswa memperoleh suatu informasi sehingga bisa dimanfaatkannya dalam berperilaku dan mengembangkan dirinya dalam kehidupan seharihari. Berkenaan dengan konformitas internalisasi siswa terhadap peraturan sekolah maka materi layanan informasi yang diberikan guru bimbingan dan konseling dapat berupa "pentingnya mematuhi peraturan sekolah dan dampak melanggar bagi siswa". Dengan materi tersebut guru bimbingan dan konseling dapat menambah pengetahuan siswa tentang fungsi peraturan untuk diterapkan serta dampaknya bila melanggar, sehingga mengembangkan kemampuan berfikir siswa, menambah wawasan dan siswa dapat mempertimbangkan bahwa melanggar aturan tersebut sangat merugikan diri baik dari segi belajar maupun dari segi psikologis.

c. Layanan Konseling Perorangan.

Layanan konseling perorngan dapat diberikan kepada siswa yang telah melanggar peraturan sekolah. Guru Bimbingan dan konseling membahas bersama siswa mengenai pelanggran yang ia buat, akibat dari pelanggarannya dan sikap dan perilaku yang seharusnya ia lakukan sebagai siswa dalam memenuhi aturan sekolah. Dengan konseling perorangan bisa memungkinkan siswa sadar dan dapat mengoptimalisasi kekuatan internalisasi dalam dirinya dalam memikirkan, mempertimbangkan serta merasakan akibat bila peraturan dilanggar.

d. Layanan Konseling kelompok.

Layanan konseling kelompok dapat diberikan kepada siswa apabila berkaitan dengan permasalahan siswa terhadap dengan peraturan sekolah. Guru bimbingan dan konseling dapat mengajak siswa-siswa berdiskusi tentang akibat bila peraturan dilanggar, serta membahas mengenai pengalaman-pengalaman siswa saat melanggar peraturan sekolah. Pembahasan bersama siswa dapat menimbulkan pemikiran siswa bahwa apabila melanggar menimbulkan perasaan bersalah, kerugian-kerugian terhadap berlangsungnya proses pembelajaran.

\section{KESIMPULAN}

Berdasarkan hasil penelitian yang dilakukan di MAN 1 Model Bukittinggi, mengenai konformitas internalisasi siswa terhadap peraturan sekolah dan implikasinya terhadap layanan bimbingan dan konseling, maka dapat diambil kesimpulan yaitu:

1. konformitas internalisasi siswa terhadap peraturan yang berkaitan dengan kedatangan dan kehadiran ke sekolah tergolong sedang dengan persentase $56 \%$

2. Konformitas internalisasi siswa terhadap peraturan dalam belajar tergolong sedang dengan persentase $54,4 \%$.

3. Konformitas internalisasi siswa terhadap peraturan umum di sekolah tergolong tinggi dengan persentase 62,1

\section{SARAN}

Berdasarkan hasil temuan dalam penelitian, maka dengan ini peneliti mengemukakan beberapa saran, yaitu sebagai berikut:

1. Diharapkan Guru bimbingan dan konseling lebih mensosialisaikan tentang peraturan sekolah dan akibatnya bila tidak dipatuhi bagi diri siswa. Serta lebih mengoptimalkan pengembangan kemampuan internalisasi siswa dalam proses pembelajaran. 
2. Bagi siswa agar lebih mengoptimalkan kekuatan dalam dirinya dengan menggunakan kemampuan berfikir, merasa, mempertimbangkan apa yang seharusnya ia lakukan sebagai siswa dalam hal mematuhi peraturan sekolah.

3. Bagi peneliti selanjutnya bisa membahas mengenai peranan guru BK dalam rangka pengembangan kemampuan internalisasi siswa di sekolah.

\section{DAFTAR RUJUKAN}

Hasbullah. 2011. Dasar-Dasar Ilmu Pendidikan (Edisi Revisi). Jakarta: Rajawali Pers.

Nana Sudjana. 2001. Penelitian Deskriptif. Bandung: Remaja Rosda Karya.

Prayitno. 2009. Dasar Teori dan Praksis Pendidikan. Jakarta : Grasindo.

Robert A.Baron \& Donn Byrne. 2005. Psikologi Sosial, Edisi Kesepuluh, Jilid 2. Jakarta: Erlangga.

Sumadi Suryabrata.2012. Psikologi Pendidikan. Jakarta: rajawali Pers

Sutjipto dan Mukti, Basori. (1989). Administrasi Pendidikan. Jakarta: Depdikbud

Tulus Tu'u. 2004. Peran Disiplin Sekolah pada Perilaku dan Prestasi Siswa. Jakarta: Grasindo. 